\title{
Model Kepuasan Orang Tua/Wali Siswa Berdasarkan Peningkatan Kualitas Pelayanan Sekolah Secara Berkelanjutan (Studi Kasus TK. Bina Mulia)
}

\author{
Muhamad Khaerudin ${ }^{1}$, Dwi Budi Srisulistiowati ${ }^{1{ }^{\star}}$ Siti Setiawati ${ }^{1}$ \\ ${ }^{1}$ Fakultas IImu Komputer, Universitas Bhayangkara Jakarta Raya, Jl.Perjuangan \\ No.81, Marga Mulya, Kec.Bekasi Utara, Kota Bekasi, Jawa Barat 17143, \\ muhammad.khaerudin@dsn.ubharajaya.ac.id,dwibudi@dsn.ubharajaya.ac.id. \\ siti.setiawati@dsn.ubharajaya.ac.id \\ * Korespondensi: e-mail: dwibudi@dsn.ubharajaya.ac.id
}

Diterima: 25 Juni 2021; Review: 26 Juni 2021; Disetujui: 29 Juni 2021; Diterbitkan: 30 Juni 2021

\begin{abstract}
Kindergarten. Bina Mulia Cibitung is a school engaged in early childhood education. Customer satisfaction survey is certainly needed to know the response of parents / guardians of students to the quality of service. But during this kindergarten. Bina Mulia has not conducted a survey on the satisfaction of parents of students to the services performed by teachers and administrative personnel. In anticipation of things that the school did not want during this pandemic, the survey was done not directly but online. Respondents to this survey are all parents / guardians of students both still active in school and who have graduated. This research is planned on an ongoing basis with the aim of knowing the level of satisfaction of parents / guardians to school services. In addition, this research aims to produce an online survey application that is integrated with the survey management information system, while the CSI method to measure customer satisfaction. Analysis of survey results is calculated using customer satisfaction index (CSI) method. CSI is a quantitative analysis in the form of a percentage of the number of parents / guardians of students to this service satisfaction survey.
\end{abstract}

Keywords : Service, Parent/Guardian, Customer Satisfaction Index

\begin{abstract}
Abstrak
Taman kanak-kanak (TK) Bina Mulia Cibitung merupakan sekolah yang bergerak dibidang pendidikan anak usia dini. Survei kepuasan pelanggan tentunya dibutuhkan untuk mengetahui respon orang tua/wali siswa, terhadap kualitas layanan. Namun selama ini TK. Bina Mulia belum melakukan survei terhadap kepuasan orang tua siswa terhadap pelayanan yang dilakukan oleh guru maupun tenaga administrasi. Untuk mengantisipasi hal-hal yang tidak diinginkan oleh pihak sekolah selama pandemi ini survei dilakukan tidak secara langsung tetapi secara online. Responden survai ini adalah semua orang tua/wali siswa baik yang masih aktif sekolah maupun yang sudah lulus. Penelitian ini direncanakan secara berkelanjutan dengan tujuan untuk mengetahui tingkat kepuasan orang tua/wali terhadap pelayanan sekolah. Selain itu penelitian ini bertujuan untuk menghasilkan aplikasi survei online yang terintegrasi dengan sistem informasi pengelolaan survei, sedangkan metode CSI untuk mengukur kepuasan pelanggan. Analisis hasil survei dihitung menggunakan metode Customer Satisfaction Index (CSI). CSI merupakan analisis kuantitatif berupa persentase jumlah orang tua/wali siswa terhadap survei kepuasan pelayanan ini
\end{abstract}

Kata kunci : Pelayanan, Orang tua/wali, Customer Satisfaction Index 


\section{Pendahuluan}

Kepuasan dan kepercayaan orang tua/wali menjadi permasalahan yang paling dominan pada setiap unit usaha yang bergerak pada bidang pendidikan, terutama pendidikan anak usia dini, akan tetapi proses untuk memenuhi kepuasan orang tua/wali merupakan hal yang sangat sulit. Kesulitan tersebut dikarenakan oleh begitu banyak faktor yang dapat mempengaruhi tingkat pencapaian kepuasan orang tua/wali sebagai pelanggan. Kualitas pelayanan sekolah yang diberikan kepada siswa dan orang tua siswa menjadi salah satu faktor kebutuhan dan keinginan konsumen yang bervariasi dalam proses memilih dan menentukan produk jasa yang akan mereka gunakan, serta semakin kritisnya konsumen dalam dominan yang menjadi pertimbangan terhadap tingkat kepuasan yang dirasakan.

Kebutuhan dan keinginan orang tua/wali sebagai pelanggan yang bervariasi dalam menilai bentuk pelayanan yang diberikan, serta semakin kritisnya pelanggan dalam menentukan pilihan sekolah untuk anaknya menjadi salah satu faktor yang membuat persaingan antar usaha dibidang pendidikan anak usia dini semakin ketat, sehingga manajemen sekolah harus berusaha dan menentukan strategi yang terbaik untuk memberikan pelayanan tanpa mengesampingkan aspek pendidikan sebagai core bisnisnya.

TK. Bina Mulia Cibitung merupakan lembaga pendidikan anak usia dini bergerak dibidang pendidikan anak usia dini, tentu berupaya untuk mendapatkan dan mempertahankan pelanggan yaitu orang tua/wali siswa. Oleh karena itu survei kepuasan pelanggan dibutuhkan untuk mengetahui respon pelanggan terhadap kualitas layanan yang diberikan dan sebagai salah satu saluran komunikasi antara pihak manajemen TK. Bina Mulia dengan pelanggan. Adanya survei kepuasan pelanggan diharapkan dapat memberikan feedback dan masukan untuk meningkatkan kualitas pelayanan.

Studi (Andaleeb, 2006), menyatakan dengan membuat modifikasi dimensi kualitas pelayanan menunjukkan adanya pengaruh yang positif tiga dimensi kualitas pelayanan yaitu, responsiveness, reliability dan price terhadap kepuasan pelanggan. Dimensi responsiveness merupakan faktor yang paling berpengaruh terhadap kepuasan konsumen.

Studi (Mukherjee. A., 2005), menemukan lima dimensi kualitas pelayanan merupakan faktor yang penting bagi kepuasan nasabah. Dimensi kualitas pelayanan responsiveness merupakan faktor terpenting bagi konsumen bank di India diikuti oleh reliability, empathy, tangible dan assurance.

Definisi kepuasan pelanggan menurut (Udiutomo, 2011), dalam mengatakan bahwa "Kepuasan Pelanggan merupakan suatu tingkatan dimana kebutuhan, keinginan dan harapan dari pelanggan akan dapat terpenuhi atau terlampaui melalui suatu transaksi yang akan mengakibatkan terjadinya pembelian ulang atau kesetiaan yang terus berlanjut". Penelitian yang dilakukan oleh (Rangkuti, 2006), mendefinisikan kepuasan pelanggan sebagai respon pelanggan terhadap ketidaksesuaian antara tingkat kepentingan sebelumnya dan kinerja actual yang dirasakannya setelah pemakaian. 
Hasil survei nantinya akan dianalisa menggunakan metode Customer Satisfaction Index (CSI). CSI merupakan analisis kuantitatif berupa persentase pelanggan yang senang dalam suatu survei kepuasan pelanggan. Metode ini digunakan untuk mengetahui tingkat kepuasan pelanggan secara keseluruhan dengan memperhatikan tingkat kepentingan dari atribut produk maupun jasa. Metode CSI mempunyai kelebihan yaitu efisien (tidak hanya indeks kepuasan tetapi sekaligus memperoleh informasi yang berhubungan dengan dimensi/atribut yang perlu diperbaiki), mudah digunakan dan sederhana, menggunakan skala yang memiliki sensivitas dan reabilitas cukup tinggi.

Dengan menggunakan metode Customer Satisfaction Index (CSI) untuk mengetahui tingkat kepuasan pelanggan terhadap penggunaan jasa yang diberikan serta untuk mengetahui prioritas perbaikan pelayanan yang harus dilakukan oleh manajemen sekolah.

\section{Metode Penelitian}

Kepuasan pelanggan (Customer Satisfaction) ditentukan oleh persepsi pengguna atas performance (kinerja) produk/layanan dalam memenuhi harapan pelanggan/pengguna. Pengguna akan merasa puas apabila harapannya terpenuhi atau akan sangat puas jika harapannya terlampaui (Irawan, 2002). Tingkat kepuasan pengguna tersebut dapat diukur dengan suatu metode yang dinamakan Customer Satisfaction Index (CSI).

Customer satisfaction index digunakan untuk mengetahui tingkat kepuasan pengguna jasa secara menyeluruh dengan melihat tingkat kinerja dan tingkat kepentingan atau harapan dari atribut-atribut jasa pelayanan (Devani, 2016).

Analisis Customer Satisfaction Index (CSI) digunakan untuk mengetahui tingkat kepuasan secara menyeluruh dengan menggunakan kriteria nilai. Langkah-langkah perhitungan Customer Satisfaction Index (CSI) adalah sebagai berikut :

a. Menentukan Mean Importance Score (MIS) dan Mean Satisfaction Score (MSS). Mean Importance Score (MIS) adalah rata-rata dari skor kepentingan suatu atribut.. Sedangkan Mean Satisfaction Score (MSS) adalah rata-rata skor untuk tingkat kepuasan yang berasal dari kinerja jasa yang dirasakan oleh pelanggan.

b. Menghitung Weight Factor (WF) atau faktor tertimbang. Bobot ini merupakan persentase nilai MIS per indikator terhadap total MIS seluruh indikator.

c. Menghitung Weight Score (WS) atau skor tertimbang. Bobot ini merupakan perkalian antara WF dengan rata-rata tingkat kepuasan.

d. Menentukan Customer Satisfaction Index (CSI)

CSI memberikan data yang jelas mengenai tingkat kepuasan pelanggan sehingga pada satuan waktu tertentu dapat melakukan evaluasi secara berkala untuk memperbaiki apa yang kurang dan meningkatkan pelayanan. 
Tabel 1. Customer Satisfaction Index (CSI)

\begin{tabular}{l|c|c|c|c}
\hline \multirow{2}{*}{ No } & \multirow{2}{*}{ Atribut } & Mean Importance & Weight Factor & Skor (S) \\
\cline { 3 - 5 } & & Score (MIS) & (WF) & \\
\hline 1 & & & & \\
\hline 3 & & & & \\
\hline 4 & & & & \\
\hline 5 & & & & \\
\hline & Jumlah & Total $=\mathrm{Y}$ & & Total = S \\
\hline
\end{tabular}

Sumber : Hasil Penelitian (2021)

Perhitungan CSI pada tabel 1 adalah Nilai rata-rata pada kolom kepentingan (I) dijumlahkan sehingga diperoleh $\mathrm{Y}$ dan juga hasil kali I dengan $\mathrm{P}$ pada kolom skor (S) dijumlahkan dan diperoleh T. CSI diperoleh dari perhitungan (T/5Y) $\times 100 \%$., Nilai 5 (pada $5 Y$ ) adalah nilai maksimum yang digunakan pada skala pengukuran. CSI dihitung dengan rumus: $C S I=T / 5 Y \times 100 \%$

Keterangan :

$\mathrm{T}=$ Nilai Total Dari CSI

$5=$ Nilai Maksimum Pada Skala Pengukuran

Y= Nilai Total Dari Kolom Harapan

Tabel 2. Kriteria Tingkat Kepuasan

\begin{tabular}{c|c|c}
\hline NO & NILAI CSI (\%) & KETERANGAN CSI \\
\hline 1 & $81 \%-100 \%$ & Sangat Puas \\
\hline 2 & $66 \%-80,9$ & Puas \\
\hline 3 & $51 \%-65,9 \%$ & Cukup Puas \\
\hline 4 & $35 \%-50,9 \%$ & Kurang Puas \\
\hline 5 & $0 \%-34,9 \%$ & Tidak Puas \\
\hline
\end{tabular}


Nilai maksimum CSI adalah $100 \%$. Nilai CSI 50\% atau lebih rendah menandakan kinerja pelayanan yang kurang baik. Nilai CSI $80 \%$ atau lebih tinggi mengindikasikan pengguna merasa puas terhadap kinerja pelayanan Laravel merupakan framework PHP yang menekankan pada kesederhanaan dan fleksibilitas pada desainnya.

Laravel Framework merupakan sebuah kerangka kerja pemrograman yang berbasis open source yang dipakai oleh banyak developer dari seluruh dunia (Mulyadi, 2015). Menurut Mulyadi, kemudahan penggunaan dan dokumentasi yang lengkap menjadi salah satu faktor mengapa Laravel menjadi primadona dalam beberapa tahun terakhir.

Laravel adalah framework open source PHP berbasis web gratis yang dibuat oleh Taylor Otwell dan ditujukan untuk pengembangan aplikasi web mengikuti model-view-controller (MVC) atau pola arsitektur. Beberapa fitur dari Laravel adalah pengembangan sistem modulmodul yang dapat dimanajemen, mengenalkan cara yang berbeda untuk mengakses database relasional, utilitas yang membantu dalam penyebaran aplikasi dan pemeliharaan yang mudah (Indrayani, 2011).

\section{Hasil dan Pembahasan}

Sebuah penelitian ilmiah baik dalam bentuk jurnal penelitian maupun prosiding biasanya diperlukan sebuah metode yang terstruktur dengan tahapan - tahapan yang jelas, sehingga dapat membantu proses penulisan laporan dan memudahkan penyelesaian permasalahan yang dibahas. Tahapan metode penelitian yang akan dilaksanakan adalah :

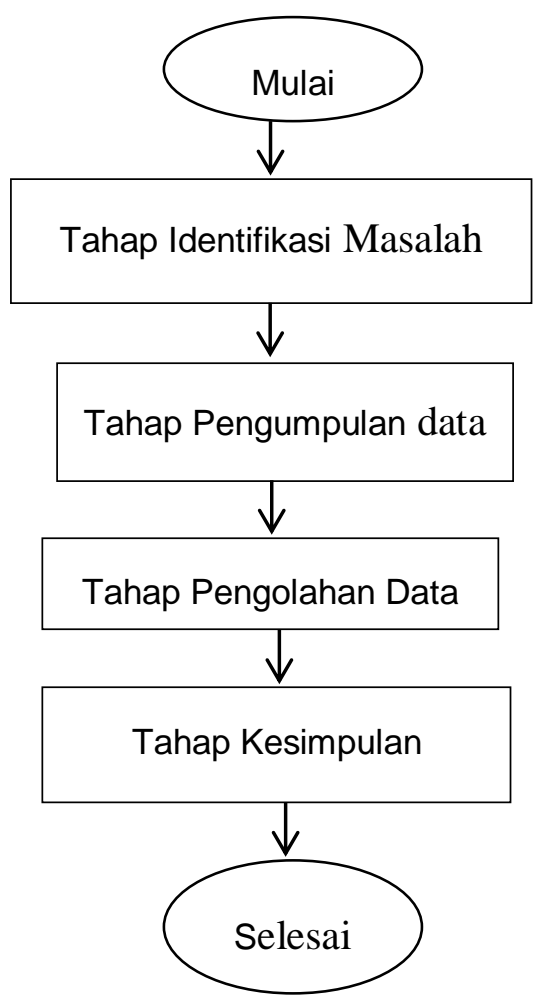

Sumber : Hasil Penelitian (2021)

Gambar 1. Kerangka Penelitian 
Tahap identifikasi masalah dimulai dari bagaimana penulis mengidentifikasi masalah yang ada di lapangan sesuai dengan topik yang dibahas, kemudian merumuskan masalah berdasarkan identifikasi masalah yang ditemui di lapangan dan menentukan studi literatur yang sesuai. Tahap pengumpulan data dimulai dari tahap pembuatan kuisioner, menyebarkan kuisioner secara terbuka sampai dengan menghitung hasil kuisioner. Tahap pengolahan data dimulai dari tahap perhitungan data hasil kuisioner dengan metode CSI dan menganalisa hasil perhitungan dan tahap terakhir membuat kesimpulah hasil perhitungan.

\subsection{Pembuatan Kusioner}

Untuk kepentingan pengolahan data penelitian dan untuk mengimplementasikan metode CSI, maka dibuatlah kuesioner yang nanti akan diisi oleh orang tua/wali dan menghasilkan data berupa tingkat kepuasan yang telah dicapai. Adapun dalam pembuatan kuesioner tersebut diperlukan beberapa langkah yang harus dilakukan, yaitu:

a. Menentukan Skala Tingkat Kepentingan (Importance)

Sebagai pedoman bagi pelanggan untuk menilai tingkat kepentingan kualitas pelayanan.

b. Menentukan Skala Tingkat Kepuasan/Kinerja (Performance)

Sebagai pedoman bagi pelanggan untuk menilai tingkat kinerja kualitas pelayanan.

c. Menentukan Indikator Pertanyaan Dalam mengukur faktor kualitas pelayanan digunakan dua indikator yaitu Usability Information Quality, Interaction Quality.

Setiap pertanyaan yang diajukan terdiri atas 5 (lima) kategori jawaban yaitu pilihan 1. berarti sangat tidak puas, pilihan 2 berarti tidak puas, pilihan 3 berarti netral, pilihan 4 berarti puas, dan pilihan 5 berarti sangat puas. Masing-masing kategori disusun berdasarkan skala likert.

Tabel 3. Tabel Indikator Pertanyaan

\begin{tabular}{|c|c|c|}
\hline NO & & PERTANYAAN \\
\hline \multirow{2}{*}{\multicolumn{2}{|c|}{1}} & Interaksi antara orang tua/wali dengan pendidik dan tenaga \\
\hline & & mudah dilakukan \\
\hline \multirow{2}{*}{\multicolumn{2}{|c|}{2}} & Tanggapan atas keluhan orang tua/wali terhadap permasalahan \\
\hline & & anak didik sesuai dengan harapan \\
\hline & 3 & Ketersediaan tempat parkir memadai \\
\hline & 4 & Kenyamanan dan kebersihan ruang \\
\hline & 5 & Ketepatan waktu belajar dan jam operasional sekolah \\
\hline & 6 & Keramahan pendidik dan tenaga kependidikan dalam melayani \\
\hline
\end{tabular}

Sumber : Hasil Penelitian (2021) 


\subsection{Analisis Kebutuhan Sistem}

Analisis kebutuhan sistem dilakukan untuk menganalisis semua kebutuhan informasi utama dari pengguna sehingga sistem yang dihasilkan dapat memenuhi kebutuhan pengguna. Dengan mengetahui kebutuhan pengguna maka akan mempermudah pendefinisian masalah dan menentukan langkah-langkah yang harus dilakukan. Selain itu hal lain yang harus dilakukan adalah mendefinisian kebutuhan informasi, kriteria kinerja sistem, dan identifikasi jenis input yang diinginkan pengguna.

\subsection{Merancang Kebutuhan Sistem}

Tahap merancang kebutuhan sistem merupakan tahap untuk menspesifikasikan bagaimana sistem dapat memenuhi kebutuhan informasi pengguna. Untuk dapat memenuhi kebutuhan pengguna, sistem ini akan memerlukan beberapa tahap desain seperti desain input, desain output, desain basis data, desain proses dan desain interface. Untuk memenuhi kebutuhan informasi survai, maka langkah awal yang harus ditempuh adalah mengetahui terlebih dahulu sistem survai yang akan dibuat, hal ini tentu akan memudahkan dalam membuat desain awal. Desain ini mencakup aspek aspek penting dari aplikasi dan sistem survei, yang memberikan gambaran kepada pengguna.

UML (Unified Modeling Language) adalah salah satu standar bahasa yang banyak digunakan di dunia industri untuk mendefinisikan kebutuhan, membuat analisis dan desain alur suatu sistem, serta dapat menggambarkan arsitektur dalam suatu pemrograman yang berorientasi objek (Rosa, 2014).

Menurut (Gata, 2013), Unified Modeling Language (UML) adalah bahasa spesifikasi standar yang dipergunakan untuk mendokumentasikan, menspesifikasikan dan membangun perangkat lunak. UML merupakan metodologi dalam mengembangkan sistem berorientasi objek dan juga merupakan alat untuk mendukung pengembangan sistem. Alat bantu yang digunakan dalam perancangan berorientasi objek berbasiskan UML adalah sebagai berikut :

\section{a. Use Case Diagram}

Use case diagram merupakan pemodelan untuk kelakuan (behavior) sistem informasi yang akan dibuat. Use case digunakan untuk mengetahui fungsi apa saja yang ada di dalam sistem informasi dan siapa saja yang berhak menggunakan fungsi-fungsi tersebut.

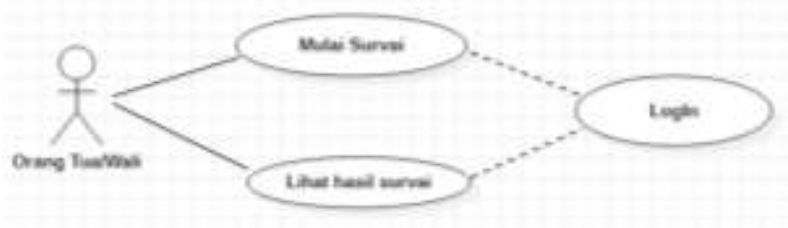

Sumber : Hasil Penelitian (2021)

Gambar 2. Diagram Use Case Pelanggan 


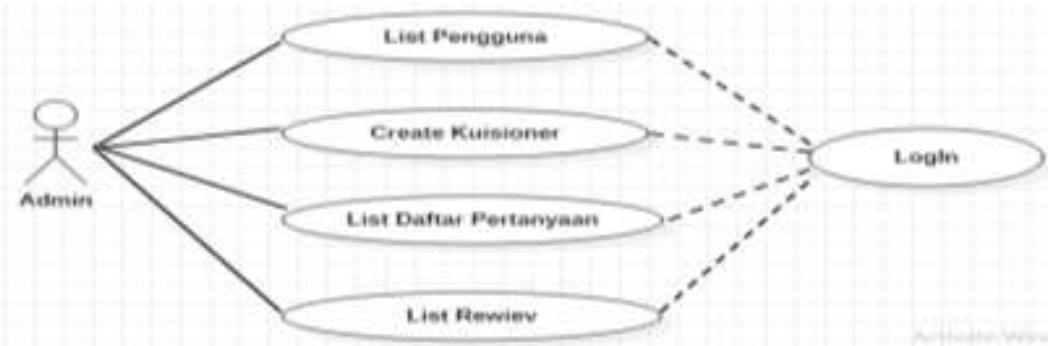

Sumber : Hasil Penelitian (2021)

Gambar 3. Diagram Use Case Admin

b. Diagram Aktivitas (Activity Diagram)

Activity Diagram menggambarkan workflow (aliran kerja) atau aktivitas dari sebuah sistem atau proses bisnis.

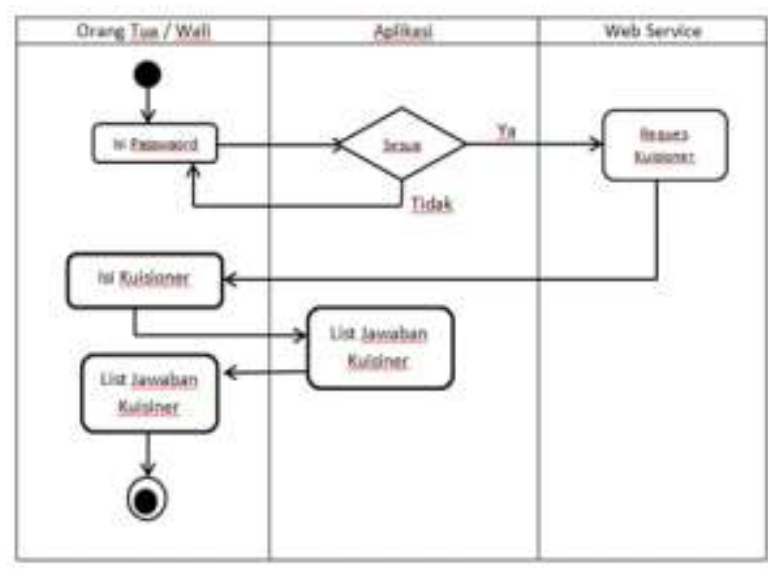

Sumber : Hasil Penelitian (2021)

Gambar 4. Diagram acrivity pelanggan

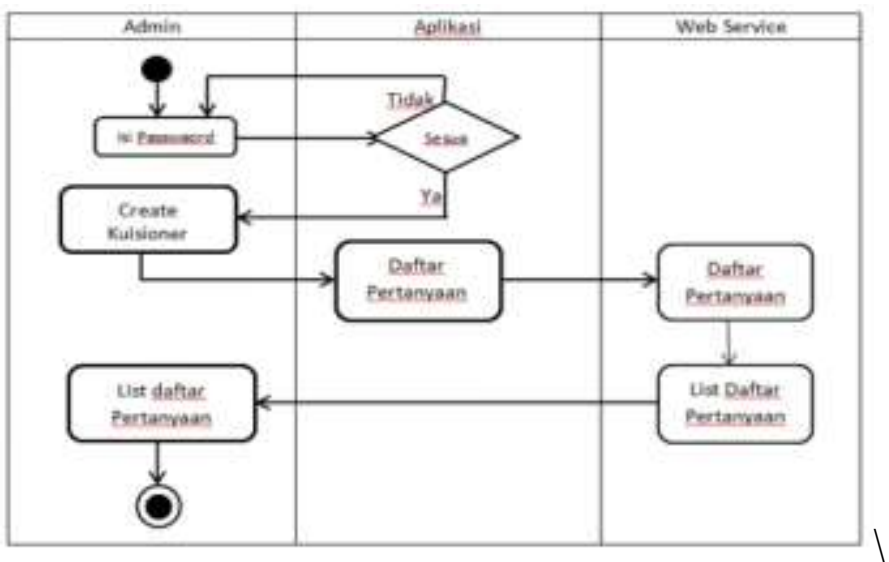

Sumber : Hasil Penelitian (2021)

Gambar 5. Diagram Activity Admin 
c. Diagram Urutan (Sequence Diagram)

Sequence Diagram menggambarkan kelakuan objek pada use case dengan mendeskripsikan waktu hidup objek dan pesan yang dikirimkan dan diterima antar objek.

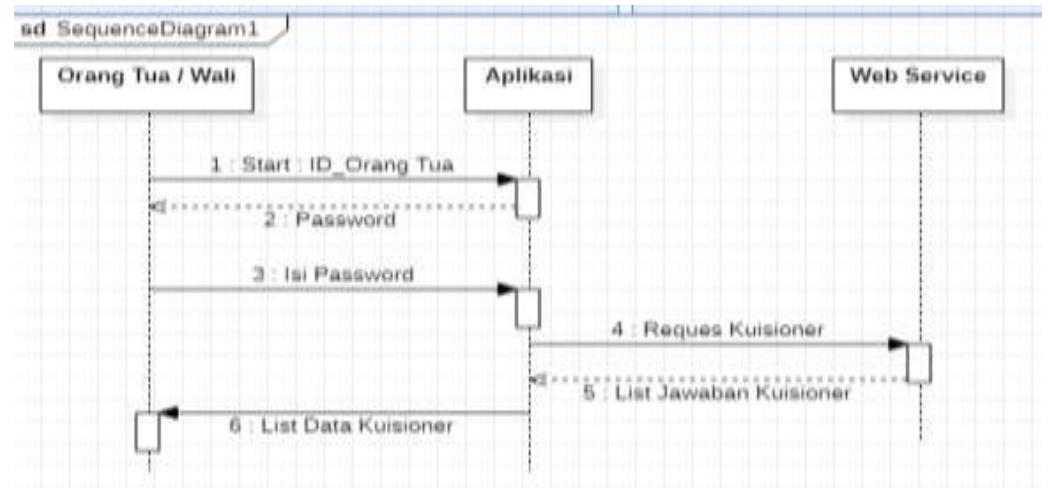

Sumber : Hasil Penelitian (2021)

Gambar 6. Diagram Sequence Pelanggan

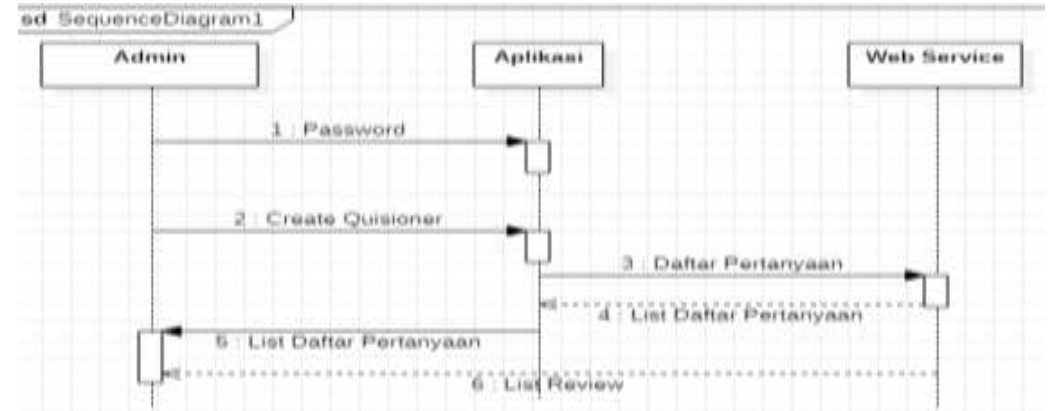

Sumber : Hasil Penelitian (2021)

Gambar 7. Diagram Sequence Admin

\subsection{Perhitungan dengan Customer Satisfaction Index}

\subsubsection{Contoh perhitungan manual}

Untuk memberikan gambaran yang jelas tentang perhitungan hasil kuisioner dengan menggunakan metode CSI, berikut ini adalah contoh perhitungannya dengan menggunakan 6 responden.

Tabel 4. Tabel Kepentingan untuk MIS (I)

\begin{tabular}{|c|c|c|c|c|c|c|}
\hline \multirow{2}{*}{$\begin{array}{c}\text { No } \\
\text { Kuisioner }\end{array}$} & \multicolumn{4}{|c|}{ Responden } & \multirow{2}{*}{ Jumlah } & \multirow{2}{*}{$\begin{array}{l}\text { Rata - } \\
\text { Rata }\end{array}$} \\
\hline & 1 & 2 & 3 & 4 & & \\
\hline 1 & 1 & 2 & 2 & 3 & 16 & 4 \\
\hline 2 & 2 & 3 & 3 & 4 & 12 & 3 \\
\hline
\end{tabular}




\begin{tabular}{c|c|c|c|c|c|c}
\hline 3 & 3 & 1 & 1 & 3 & 14 & 3.5 \\
\hline 4 & 1 & 2 & 2 & 1 & 18 & 4.5 \\
\hline 5 & 3 & 3 & 2 & 2 & 14 & 3.5 \\
\hline 6 & 2 & 3 & 1 & 4 & 14 & 3.5 \\
\hline
\end{tabular}

Sumber : Hasil Penelitian (2021)

Tabel 5. Tabel Kepuasan Pelanggan untuk WF (P)

\begin{tabular}{|c|c|c|c|c|c|c|}
\hline \multirow{2}{*}{$\begin{array}{c}\text { No } \\
\text { Kuisioner }\end{array}$} & \multicolumn{4}{|c|}{ Responden } & \multirow{2}{*}{ Jumlah } & \multirow{2}{*}{$\begin{array}{l}\text { Rata - } \\
\text { Rata }\end{array}$} \\
\hline & 1 & 2 & 3 & 4 & & \\
\hline 1 & 2 & 3 & 3 & 4 & 12 & 3 \\
\hline 2 & 1 & 2 & 2 & 1 & 18 & 4.5 \\
\hline 3 & 1 & 2 & 1 & 1 & 19 & 4.75 \\
\hline 4 & 3 & 3 & 1 & 2 & 15 & 3.75 \\
\hline 5 & 4 & 2 & 3 & 3 & 12 & 4 \\
\hline 6 & 1 & 2 & 1 & 1 & 19 & 4.75 \\
\hline
\end{tabular}

Sumber : Hasil Penelitian (2021)

Tabel 6. Customer Satisfaction Index (CSI)

\begin{tabular}{c|c|c|c}
\hline No & MIS & WF & Skort \\
Kuisioner & $(\mathrm{I})$ & $(\mathrm{P})$ & $(\mathrm{IXP})$ \\
\hline 1 & 4 & 3 & 12 \\
\hline 2 & 3 & 4.5 & 13.5 \\
\hline 3 & 3.5 & 4.75 & 16.625 \\
\hline 5 & 4.5 & 3.75 & 16.875 \\
\hline 6 & 3.5 & 4 & 14 \\
\hline
\end{tabular}

Sumber : Hasil Penelitian (2021) 
Hasil Perhtungan CSI adalah :

$$
\begin{aligned}
& \text { CSI }=\frac{T}{5 Y} \times 100 \% \\
& C S I=\frac{89.625}{5 * 22} \times 100 \%=81.48 \%
\end{aligned}
$$

\subsubsection{Implementasi Metode ICS}

Guna memberikan gambaran yang jelas tentang implementasi metode ICS ini berikut ini ditampilkan halaman utama data hasil kuesioner pelanggan (Orang tua/wali murid) yang kemudian menghasilkan index kepuasan pelanggan.

\section{Dashboard statistics Overview}

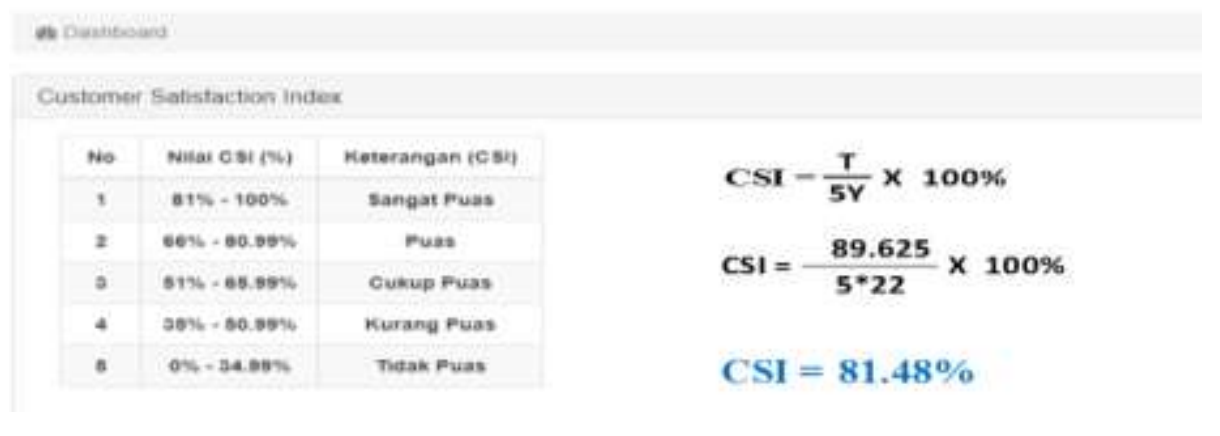

Sumber : Hasil Penelitian (2021)

Gambar 6. Dashboard

Sistem ini juga dapat menampilkan hasil rata rata pada tingkat kepentingan

\begin{tabular}{|c|c|c|c|c|c|c|c|c|c|c|c|}
\hline \multicolumn{12}{|l|}{ Importance } \\
\hline List $1 \quad \boldsymbol{\nabla}$ & \multicolumn{11}{|l|}{ Record } \\
\hline No Kuis & 1 & 2 & 3 & 4 & & \multicolumn{3}{|c|}{5} & \multicolumn{3}{|c|}{6} \\
\hline 1 & 1 & 2 & 3 & 1 & & \multicolumn{3}{|c|}{3} & \multicolumn{3}{|c|}{2} \\
\hline 2 & 2 & 3 & 1 & 2 & & \multicolumn{3}{|c|}{3} & \multicolumn{3}{|c|}{1} \\
\hline 3 & 2 & 3 & 1 & 2 & & \multicolumn{3}{|c|}{2} & \multicolumn{3}{|c|}{1} \\
\hline 4 & 3 & 4 & 3 & 1 & & \multicolumn{3}{|c|}{2} & \multicolumn{3}{|c|}{4} \\
\hline 5 & 2 & 3 & 2 & 2 & & \multicolumn{3}{|c|}{3} & \multicolumn{3}{|c|}{3} \\
\hline 6 & 1 & 1 & 2 & 2 & & \multicolumn{3}{|c|}{2} & \multicolumn{3}{|c|}{2} \\
\hline 7 & 3 & 3 & 2 & 2 & & \multicolumn{3}{|c|}{3} & \multicolumn{3}{|c|}{1} \\
\hline 8 & 2 & 2 & 1 & 1 & & \multicolumn{3}{|c|}{2} & \multicolumn{3}{|c|}{1} \\
\hline 9 & 1 & 1 & 2 & 2 & & \multicolumn{3}{|c|}{2} & \multicolumn{3}{|c|}{2} \\
\hline 10 & 2 & 3 & 4 & 4 & & \multicolumn{3}{|c|}{3} & \multicolumn{3}{|c|}{2} \\
\hline Total & 41 & 35 & 39 & 41 & & \multicolumn{3}{|c|}{35} & \multicolumn{3}{|c|}{41} \\
\hline Rata rata & 4.1 & 3.5 & 3.9 & 4.1 & & \multicolumn{3}{|c|}{3.5} & \multicolumn{3}{|c|}{4.1} \\
\hline List 1 to 10 of 55 & & & & Previous & 1 & 2 & 3 & 4 & 5 & 6 & Next \\
\hline
\end{tabular}
seperti gambar dibawah ini :

Sumber : Hasil Penelitian (2021)

Gambar 7. Hasil Rata-Rata Pada Tingkat Kepentingan 


\section{Kesimpulan}

a. Memudahkan pelanggan dalam hal ini orang tua/wali dalam memberikan masukan kepada pihak sekolah yaitu dengan menggunakan media survai dapat dilakukan kapanpun.

b. Dengan diterapkannya implementasi CSI untuk menghitung hasil survei kepuasan pelanggan. Persentase nilai CSI pada TK. Bina Mulia sebesar $81,48 \%$ yang artinya pelanggan sangat puas terhadap pelayanan dari tenaga kependidikan maupun tenaga pendidik.

\section{Daftar Pustaka}

Andaleeb, S. C. (2006). Customer Satisfaction in the Restaurant Industry: An Examination of the Transaction-Specific Model. Journal of Services Marketing, 20 (1), 3-11. doi:https://doi.org/10.1108/08876040610646536

Devani, V. R. (2016). ANALISIS KEPUASAN PELANGGAN DENGAN MENGGUNAKAN METODE CUSTOMER SATISFACTION INDEX (CSI) DAN POTENTIAL GAIN IN CUSTOMER VALUE (PGCV). Jurnal IImiah Rekayasa dan Manajemen Sistem Informasi, 2 (2), 24-28. doi:http://dx.doi.org/10.24014/rmsi.v2i2.2605

Gata, W. G. (2013). Sukses Membangun Aplikasi Penjualan dengan Java. Jakarta: ELex Media Komputindo.

Indrayani, E. (2011). PENGELOLAAN SISTEM INFORMASI AKADEMIK PERGURUAN TINGGI BERBASIS TEKNOLOGI INFORMASI DAN KOMUNIKASI (TIK). Jurnal Penelitian Pendidikan, 11 (1), 51-67. Retrieved from http:/jurnal.upi.edu/penelitianpendidikan/view/437

Irawan, H. (2002). Prinsip Kepuasan Pelanggan. Jakarta : PT Elex Media Komputindo.

Mukherjee. A., N. P. (2005). An empirical assessment of comparative approaches to service quality measurement. Journal of Services Marketing, 19 (3), 174-84. doi:https://doi.org/10.1108/08876040510596858

Mulyadi. (2015). Sistem Akuntansi. Jaakrta: Salemba Empat.

Rangkuti, F. (2006). Measuring Customer Satisfaction. Jakarta: PT Gramedia Pustaka Utama.

Rosa, A. S. (2014). Rekayasa Perangkat Lunak Terstruktur dan Berorientasi Objek. Bandung: Informatika.

Udiutomo, P. (2011). ANALISA TINGKAT KEPUASAN SISWA TERHADAP LAYANANPROGRAM SMART EKSELENSIA INDONESIA TAHUN 2011. Jurnal Pendidikan Dompet Dhuafa, 1 (1), 50-66. Retrieved from https://jurnal.makmalpendidikan.net/index.php/JPD/article/view/23 